Received: $26 / 07 / 2018$

Revision: 25/10/2018

Accepted: $30 / 10 / 2018$

OnlineFirst: 04/11/2018

\title{
Improving Students' Critical Thinking Skills in Cell-Metabolism Learning Using Stimulating Higher Order Thinking Skills Model
}

\section{Arnita Cahya Saputri}

Postgraduate Student, Faculty of Teacher Training and Education, Universitas Sebelas Maret, Surakarta, Indonesia, arnitacahyasaputri26@student.uns.ac.id

\section{Sajidan}

Prof., Faculty of Teacher Training and Education, Universitas Sebelas Maret, Surakarta, Indonesia, sajidan@fkip.uns.ac.id

\section{Yudi Rinanto}

Dr., Faculty of Teacher Training and Education, Universitas Sebelas Maret, Surakarta, Indonesia,yudi.rinanto@gmail.com

\section{Afandi}

Postgraduate Student, Faculty of Teacher Training and Education, Universitas Sebelas Maret, Surakarta, Indonesia, afandi@fkip.untan.ac.id

\section{Nanik Murti Prasetyanti}

Teacher, SMA Negeri 3 Surakarta, Surakarta, Indonesia, nanikmp@gmail.com

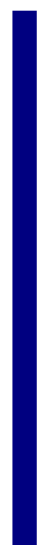

Critical thinking skills are one of the important skills in dealing with the demands and challenges of the 21 st century. This study aims to determine the effectiveness of Stimulating Higher-Order-Thinking Skills (Stim-HOTs) model in improving students' critical-thinking skills on cell metabolism topic. This research is quasiexperimental research with pretest-posttest control group design in one high school in Surakarta, Indonesia in 2017/2018 academic year with one class as the experimental class by using Stim-HOTs model while the other class as the existing class that uses discovery learning model. The data were obtained by using criticalthinking skill test instrument in the form of essay that has been through expert validations, namely the validation from the education and evaluation expert, biology expert, and the certified high school Biology teacher, as well as the empirical validation through try-out. The result showed that the average score of critical-thinking skill gain score calculation in the experimental class was higher by 0.66 compared to the existing class of 0.51 .

Keywords: critical-thinking skill, cell metabolism, stimulating HOTs, teaching, learning

Citation: Saputri, A. C., Sajidan, Rinanto, Y., Afandi, \& Prasetyanti, N. M. (2019). Improving Students' Critical Thinking Skills in Cell-Metabolism Learning Using Stimulating Higher Order Thinking Skills Model. International Journal of Instruction, 12(1), 327-342. https://doi.org/10.29333/iji.2019.12122a 


\section{INTRODUCTION}

The development of the $21^{\text {st }}$ century requires everyone to have the skills to equip themselves in the face of developments in the era of globalization and disruption innovation (Lin, Li, \& Wu, 2018; Sing \& Kong, 2017). According to the $21^{\text {st }}$ Century Partnership Learning Framework (P21) (2015), there are a number of competencies or skills that must be possessed in the $21^{\text {st }}$ century - critical-thinking skills and problem solving, communication and collaboration skills, creative and updating skills, information and communication technology literacy skills, contextual learning skills, as well as information and media literacy skills. These skills can be trained to students early in the learning process at schools and become a priority learning objective (Chu, Reynold, Tavares, \& Notari, 2017; Sripongwiwat, Bunterm, Srisawat, \& Tang, 2016).

$21^{\text {st }}$-century skills in the learning process in Indonesia are developed to be trained in the 2013 curriculum. Students who have critical-thinking skills will strive to provide logical reasoning in understanding and making complex choices, as well as understanding the interconnections between systems (Husamah, Fatmawati, \& Setyawan, 2018). Therefore, these skills need to be familiarized to be trained in school learning so that they become a provision of the students to face the future through the interaction between teachers and students (Mahanal, Zubaidah, Bahri, \& Dinnuriya, 2016).

The lack of critical thinking skills is the fact encountered in education both nationally and internationally. The low critical-thinking skills at the national level are found in many parts of Indonesia, as evidenced by the results of the study by Mahanal et al. (2016) in Malang and Hairida (2016) in Pontianak. International researches conducted by Adeyemi (2012) in Nigeria, Taleb \& Chadwick (2016) in Dubai, and Marin \& Halpern (2011) in the United States also show that students' thinking skills in some countries in the world are still low. The low level of thinking skills of Indonesian students can also be seen in the study of the Program for International Student Assessment (PISA). The results of a once-a-year study using instruments to test Science literacy closely related to high-order-thinking skills show that Indonesia ranked $60^{\text {th }}$ out of 65 participating countries in 2009, the $64^{\text {th }}$ of 65 participating countries by 2012, and $69^{\text {th }}$ of the 75 participating countries by 2015 (OECD, 2010; 2014; 2016). These results indicate that Indonesian students have not yet been trained to think high level so that the results of each PISA-held test still put Indonesia at the bottom and generally still below the average score standard of the Organization for Economic, Cooperation, and Development (OECD) (Suprapto, 2016).

The fact is that at a high school in the city of Surakarta, Indonesia, the students' criticalthinking skills are still low. This fact is seen from the symptoms of the problem that dominates the results of observations during the process of Biology learning in the classroom. The symptoms of the problem that arise include (1) the students were less careful in analyzing a problem; (2) it was difficult for them to do high-level questions (C4-C6); (3) some students were passive while doing group-works; (4) many of them found it difficult to connect concepts and problems; (5) and some of them had difficulty expressing their opinions during the discussion. The results of the observations were then supported by the results of the initial profile test containing six aspects of critical- 
thinking skills according to the indicators of Facione (2015) in the $12^{\text {th }}$ grade of Mathematics and Science showing that there are only two aspects in good criterion - on the evaluation aspect with the acquisition of $78 \%$ and on self-regulation of $66 \%$ while the other four aspects are still insufficient criterion i.e. 52\% interpretation, 56\% analysis, $52 \%$ conclusion, and $42 \%$ explanation (Saputri, Sajidan, \& Rinanto, 2018). Therefore, it can be concluded that the low critical-thinking skills are still a real problem occurred at high schools in Surakarta, Indonesia.

Low students' critical-thinking skills are a problem to be solved (Aun \& Kaewurai, 2017). Solution attempts are needed to improve these skills because critical-thinking skills have a strategic value in life. When critical-thinking skills are in place, students can think neutrally, objectively, reasonably or logically, become tough thinkers and reliable problem-solvers, and generate conclusions to do something (Ennis, 2011; Facione, 2011). Critical thinking skills can be trained in many ways. Some research results using certain learning models can improve critical-thinking skills, such as the study Fuad, Zubaidah, Mahanal, \& Suarsini (2017) using three types of learning models, using Remap-NHT model, and Setiawati \& Corebima (2017) using PQ4R-TPS. Critical thinking skills can also be trained through argumentative activities as well as analysis of an idea and a question presented by the teacher (Cottrell \& Cottrell, 2005; Pithers \& Soden, 2010). The use of the model is the preferred way to solve problems related to the low students' critical-thinking skills in Biology learning at the high school in Surakarta, Indonesia because the model can be easily applied in classroom learning (Husamah et al., 2018).

The inquiry learning model is a learning model compatible with Science learning (Arsal, 2017; Jeffery, Nomee, Deane, Pollock, \& Birol, 2016; Mcnew-birren \& Kieboom, 2017; Uum, Verhoeff, \& Peeters, 2017; Wenning, 2011). The inquiry model is also an appropriate model to train students' critical-thinking skills (Haridianti \& Kuswanto, 2017). The learning model used to empower students' critical-thinking skills is a model that is able to stimulate thinking skills in the $21^{\text {st }}$ century. The model used is Stimulating Higher-Order-Thinking Skills (Stim-HOTs) model. The Stim-HOTs model is an innovative learning model based on inquiry learning developed on the basis of a number of literature reviews of learning theories that underlie how to teach students' thinking skills. This model can be used to train the aspects of students' critical-thinking skills through the activity of six syntaxes in the model; they are orientation, asking, exploring information, discussion, explanation, and self-reflection (Afandi \& Sajidan, 2017; Afandi, Sajidan, Akhyar, \& Suryani, 2017).

The results of the interviews with the students and the teachers indicate that the elusive Biology material of the $12^{\text {th }}$-grade students at the high school in Surakarta, Indonesia is cell metabolism topic. It is also reinforced from the average results of absorption analysis on some indicators of cell metabolism material at the national examination at school level during the last three years which shows that the average result of absorption of the national examination on cell metabolism material with some indicators is still in low mastery. The low learning outcomes in some national examination indicators are presumed due to the influence of the low critical thinking skills of students and the learning process that has not been optimal. 


\section{Theoretical Background}

\section{Critical Thinking Skill}

Critical thinking skill is one of the skills needed to deal with the demands of the $21^{\text {st }}$ century to deal effectively with social, scientific and practical problems in the future (Swart, 2017; Synder \& Synder, 2008). Critical thinking skill is the skill and the tendency to make and assess evidence-based conclusions (Eggen \& Kauchak, 2012). Students who have critical thinking skill will try to provide reasonable reasoning in understanding and making complex choices, and understanding interconnections between systems. In addition, students can also have the ability to compile, express, analyze, and solve problems (Husamah \& Setyaningrum, 2013). In addition, critical thinking skill is also defined as a skill that can create a powerful thinker and a reliable problem solver (Facione, 2011). Aspects of critical thinking skill in this study include aspects of interpretation, analysis, evaluation, conclusion, explanation, and selfregulation (Facione, 2015).

\section{Cell metabolism Learning}

Cell metabolism is a material in the learning of biology in Indonesia high schools which has a lot to do with the development of future trends in the 21 st century. This material discusses the metabolic processes as enzymatic reactions in the body of living things and involves various basic concepts such as anatomical physiology, biochemistry, and changes in energy. In addition, a good understanding of inorganic and organic molecules is also needed to explain how the reaction processes in catabolism and anabolism occur. Cell metabolism is an important material because it becomes a necessity for the application of biology in everyday life and various fields of science (Muspikawijaya, Iswari \& Marianti, 2017; Uzoamaka, Okafor, \& Akusoba, 2014; Vanderlelie, 2013).

\section{Stimulating Higher-Order-Thinking Skills (Stim-HOTs) Model}

The model of Stimulating Higher-Order-Thinking Skills (Stim-HOTs) is a new learning model based on inquires learning's developed through some literature-based learning which is the basis of how to teach the students' skills. This model is adjusted to encourage the liberty of students' thinking that followed by the collaborative, communicative, and ICT skills. It is also developed to stimulate the higher order thinking skills through employing the six activities: orientation, questioning, exploration, discussion, explanation, and reflection. The main principle in this model is student-centered learning that is built from interactions including: a) teacher-student, b) teacher-student-teacher, c) between students in groups, d) between groups, and teachers -between groups (Afandi \& Sajidan, 2017; Afandi, et al., 2017)

\section{The Aim of the Study}

Based on the above background description, this study aims to test whether the application of Stimulating Higher-Order-Thinking Skills (Stim-HOTs) model is effective in improving critical-thinking skills especially on cell metabolism topic. 


\section{METHOD}

\section{Research Design}

This research is quasi-experimental research with pretest-posttest control group design (Creswell, 2012). The study was conducted by implementing Stimulating Higher-OrderThinking Skills (Stim-HOTs) learning model in the experimental class whereas in the existing class, the researcher applied discovery learning model commonly used by the teachers in the school. Both classes took pretest first before receiving treatment and then took posttest. The pretest-posttest results were scored according to the scoring rubric and then analyzed statistically. The data were analysed using SPSS 22.0 for Windows to find out the results of descriptive pretest-posttest analysis, normality test with one sample Kolmogorov-Smirnov, homogeneity test with Levene test, ANCOVA test, Ngain calculation with Hake interpretation (1999), while the effect size test was done with the interpretation according to Hedges (1981), Cohen (1988), and Glass (1976) using Rstat Effect Size Calculator.

\section{Population and Sample}

The population in this study was high school students in Surakarta. The sample used in this research is the $12^{\text {th }}$-grade students of Mathematics and Science programs in the odd semester of 2017/2018 academic year with the number of 65 students. The sampling was done purposively in a high school based on the data of national examination analysis and the results of the initial profile test of critical-thinking skills. A total of 32 students were in the experimental class using the Stim-HOTs model while 33 students were in the control class using the learning model used by the teachers at the school.

\section{Research Instruments}

The data were obtained by using the critical-thinking skill test instrument in the form of essay questions which were prepared based on six indicators of critical-thinking aspects according to Facione (2015) covering interpretation, analysis, evaluation, conclusion, explanation, and self regulation which have been through expert validation consisting of the expert of education and evaluation, a biologist, and a certified high school Biology teacher as well as empirical validation through experimental tests showing that the instrument is valid and reliable. The essay test item instrument has a scoring interval of 1-4 corresponding to respective criteria. Instrument validity test was conducted using Pearson's Product Moment correlational test with the following terms: if $r_{\text {statistic }}>r_{\text {table, }}$ the item is considered as valid, and if $r_{\text {statistic }}<r_{\text {table }}$, the item is considered as invalid and is removed. The instrument of validity test obtained the lowest score of 0.515 and highest one of $0.892>f_{\text {table }}$, with 20 students as respondents with $r_{\text {value }}=0.443$, meaning that the instrument of critical thinking skill item was valid. Meanwhile, the reliability test obtained by Alpha Cronbach is $0.941>0.443$ meaning that each of items is reliable to be implemented in the experiment and existing classes. 


\section{FINDINGS}

The Descriptive Analysis Result of Pre-test and Post-test Scores of CriticalThinking Skills

The results of the descriptive analysis of pre-test and post-test of critical-thinking skills in both experimental and existing classes are presented in Table 1 below.

Table 1

The Result of Descriptive Analysis of Pre-test and Post-test Scores

\begin{tabular}{lllllll}
\hline $\begin{array}{l}\text { Kinds of } \\
\text { Tests }\end{array}$ & Classes & $\begin{array}{l}\text { Number of } \\
\text { Students }\end{array}$ & $\begin{array}{l}\text { Min } \\
\text { Scores }\end{array}$ & $\begin{array}{l}\text { Max } \\
\text { Scores }\end{array}$ & Mean & Std \\
\hline Pre-test & Experiment & 32 & 38.33 & 71.67 & 50.18 & 7.43 \\
\hline & Existing & 33 & 38.33 & 67.67 & 49.57 & 7.98 \\
\hline Post-test & Experiment & 32 & 62.67 & 96.00 & 82.61 & 8.07 \\
\hline & Existing & 33 & 53.50 & 94.00 & 74.66 & 12.35 \\
\hline
\end{tabular}

Table 1 shows the results of the descriptive analysis of critical-thinking skills given before treatment and after treatment was to the experimental and the existing classes. The test results showed that between the experimental and the existing classes, the average pre-test score is almost the same, as 50.18 and 49.57. It shows that the classes used in this study have the same capabilities. Meanwhile, the average post-test score in the experimental and control classes showed a considerable difference, that is, the average score of post-test in the experimental class is 82.61 greater than that in the existing class of 74.66 .

\section{The Analysis Result of ANCOVA Test on Students Critical Thinking Skill}

The analysis of covariance (ANCOVA) was conducted to determine whether there is a difference between the pretest and post-test critical-thinking skill both in the experimental and the existing classes. The prerequisite tests in the form of normality using Kolmogorov-Smirnov test and homogeneity tests using Levene test conducted before ANCOVA test showed that the scores of pre-test and post-test of critical-thinking skills in the experimental and the existing classes are normally distributed and homogeneous. Therefore, further test using ANCOVA test can be done. The ANCOVA test results can be seen in Table 2 below.

Table 2

The result of the ANCOVA Test on Students Critical Thinking Skill

\begin{tabular}{llllll}
\hline \multicolumn{2}{l}{ Dependent Variable: Posttest } & & & & \\
\hline Source & Type III Sum of Squares & df & Mean Square & F & Sig. \\
\hline Corrected Model & $3806.467^{\mathrm{a}}$ & 2 & 1903.234 & 28.598 & .000 \\
\hline Intercept & 1882.364 & 1 & 1882.364 & 28.284 & .000 \\
\hline Class & 895.435 & 1 & 895.435 & 13.455 & .001 \\
\hline Pretest & 2780.343 & 1 & 2780.343 & 41.777 & .000 \\
\hline Error & 4126.211 & 62 & 66.552 & & \\
\hline Total & 409287.887 & 65 & & & \\
\hline Corrected Total & 7932.679 & 64 & & & \\
\hline
\end{tabular}

a. R Squared $=, 480$ (Adjusted R Squared $=, 463$ ) 
Based on the results of the covariance analysis, F count of 13.445 with the significance of 0.001 was obtained. This significance value is less than $0.05(\mathrm{p}<0.05)$, so that $\mathrm{H}_{0}$ is rejected and the research hypothesis is accepted which shows that the Stim-HOTs model applied to the experimental class are effective in empowering students' critical-thinking skills. There is an effect of using Stim-HOTs learning models for empowering students' critical thinking skills because there are different results between the two classes tested. The effectiveness rate of the model in empowering critical-thinking skills can be known by the further test following the ANCOVA test is effect size test.

The Gain-Score Analysis Result of Pre-test and Post-test Scores of CriticalThinking Skills

The pre-test and post-test scores of critical-thinking skills are then calculated to determine the rate of increase in the results of the Stimulating Higher-Order-Thinking Skills (Stim-HOTs) model on cell metabolism topic. The summary of the results of the average Gain Score analysis on the results of critical-thinking skills tests is presented in Table 3 below.

Table 3

The Result of Gain Score Analysis of Pre-test and Post-test Scores of Critical Thinking Skills

\begin{tabular}{lll}
\hline Classes & Mean of Gain Score & Criteria \\
\hline Experimental Class & 0.66 & Medium \\
\hline Existing Class & 0.51 & Medium \\
\hline
\end{tabular}

Table 3 shows that the average gain score in the experimental class shows the results of 0.66 in the moderate category and the existing class shows the result of 0.51 in the medium category according to Hake (1999). The average score of the gain score calculation of the experimental class is higher than that of the existing class.

\section{Analysis Result of Effect Size Test}

The results of effect size test analysis using Cohen's test, Hedges's g, and Glass's with Rstat Effect Size Calculator on N-gain scores are shown in Table 4 below.

Table 4

The Analysis Result of Effect Size Test

\begin{tabular}{lllllll}
\hline \multicolumn{1}{c}{ Class } & Mean & Std & Cohen's d & Hedges's g & Glass's & Interpretation \\
\hline Experiment & 0.659 & 0.129 & 0.876 & 0.866 & 0.740 & Large \\
\hline Existing & 0.512 & 0.199 & & & & \\
\hline
\end{tabular}

The result of effect size test analysis shows that the use of the model in learning has a large effect on the empowerment of critical-thinking skills shown by the result of effect size test based on Cohen's formula d of 0.876, Hedges's g of 0.866 , and Glass's of 0.740 . 


\section{DISCUSSION}

The Stimulating Higher-Order-Thinking Skills (Stim-HOTs) model applied to the cell metabolism topic has the potential to improve critical-thinking skills as indicated by the independent sample t-test and the effect size test. The result of ANCOVA test shows the effect of using Stim-HOTs learning models for empowering students' critical thinking skills with results of the covariance analysis obtained $\mathrm{F}$ count of 13.445 and significance of 0.001 , while the result of effect size test is in the large criterion. The effectiveness rate of the Stim-HOTs model in empowering the critical-thinking skills of the effect size test analysis with Rstat Effect Size Calculator against the N-gain score shows that the use of the model in learning has a major effect on the empowerment of critical-thinking skills as indicated by the effect size test results based on Cohen's formula d of 0.876 , Hedges's $g$ of 0.866 , and Glass's of 0.740. This effect indicates that there is a large impact of applying the learning model to the aspects of students' critical-thinking skills. The result of this effect size is the impact of the treatment given to the variable to be developed (Sullivan \& Feinn, 2012). The treatment is the result of the syntactic activities of the Stimulating Higher-Order-Thinking Skills (Stim-HOTs) model based on a number of studies on learning theories that train students' thinking skills. This learning model trains the aspects of students' critical thinking skills through six syntaxes that include orientation, questioning, information exploration, discussion, explanation, and self-regulation (Afandi \& Sajidan, 2017; Afandi et al., 2017). The results of this study are relevant to the research undertaken by Fuad, Zubaidah, Mahanal, \& Suarsini (2017), Mahanal et al. (2016), and Setiawati \& Corebima (2017) stating that the learning model can improve students' critical-thinking skills.

Orientation syntax in Stim-HOTs model on cell metabolism material is effective in training the aspects of critical-thinking skill on interpretation aspect. The training of this aspect through orientation is based on the belief that in complex thinking, mastery of knowledge and understanding at the basic level require a foothold to achieve higher thinking processes. Therefore, the teacher, in this case, teaches many terms, meanings and basic material frameworks (Afandi \& Sajidan, 2017; Afandi et al., 2017). The orientation syntax becomes the first stage of learning activities in the developed module which always begins with the observation stage, the first step done by the students to start investigating the topic. The investigation is done by exploring a phenomenon that will stimulate students' curiosity (Arsal, 2017; Jeffery, Nomme, Deane, Pollock, \& Birol, 2016; Mcnew-birren \& Kieboom, 2017). This is relevant to critical-thinking skills on interpretive aspects that require students to capture and formulate categories, differences, frameworks, and to describe information so as to understand the meaning through the determination, description, and the meaning analogy of words, ideas, concepts, numbers, images, symbols, charts, graphs or specific events (Facione, 2015). The effectiveness of orientation syntax in the Stim-HOTs model in empowering criticalthinking skills is based on Piaget's view of cognitive growth and Bloom's idea of learning taxonomy. The explanation of Piaget's cognitive development theory forms the basis of the basic knowledge orientation stage of the Stim-HOTs model syntax because in connecting low-level thinking to higher-order thinking processes, teachers need to 
build schemata of previously-acquired knowledge with new information content to be taught as Piaget's view about the restructuring of information (Piaget, 2003; Schunk, 2012). Meanwhile, there is a support of basic learning theories of basic knowledge orientation stage on the syntaxes of the Stim-HOTs model because the taxonomy of thinking proposed by Bloom in the form of categories allows students to examine educational goals and implement high-order-thinking skills (Anderson \& Krathwohl, 2015).

The syntax of questioning in the Stim-HOTs model on metabolism topic is effective in training the aspects of critical thinking skills on analysis aspect. The analysis aspect is the aspect of critical-thinking skills in which students are required to identify and analyze a relationship among questions, concepts, descriptions or others intended to express trust, judgment, experience, reason, information or opinion (Facione, 2015). In this syntax, the students identified the problems obtained from the previous stage, orientation stag, and then analyzed them in the form of some questions which further lead to the main question. The questions used in this case are problematic or cases that occur around to stimulate students' thinking process (Afandi \& Sajidan, 2017; Afandi et al., 2017). Questioning syntax stimulates to create a scientific question that will lead to a process for understanding a problem-based concept and making it into a hypothesis. Students also proceeded to plan alternative problems based on previously-understood concepts (Pedaste, Mäeots, Siiman, Jong, Zacharia, \& Tsourlidaki, 2015; Lotter, Thompson, Dickenson, \& Smiley, 2016). Well-trained questioning skills will develop high-level thinking skills, curiosity competence, creativity, critical-thinking skills, and a person's character as lifelong learners (Tofade, Jamie, \& Haines, 2013; Yang, Newby, $\&$ Bill, 2005). The questioning syntax in the Stim-HOTs model based on Dewey's idea of inventive thinking and Socratic dialogue methods can tackle the aspect of analysis because students are required to ask high-level questions, so they need to do the analysis first before asking questions. This syntax of the questioning model also builds social systems between teachers and students in classroom learning (Afandi \& Sajidan, 2017; Afandi et al., 2017).

The syntax of information exploration in the Stim-HOTs model on metabolism topic is effective in training the aspects of critical thinking skills on analysis aspect. This aspect is trained in students by exploring knowledge both through laboratory activities and through literature studies to answer questions posed by conducting the good analysis. This activity is directed to individual or group activities. Laboratory activities can also improve students 'attitudes and interests in Science (Jeffrey et al., 2016). Information exploration activities require students to be able to answer the questions posed by looking for some information from several sources using either direct sources or ICT media. The role of educators at this stage is to guide students in the effort of extracting information to find relevant data to answer the questions or problems in the worksheet (Afandi \& Sajidan, 2017; Afandi et al., 2017). The information exploration stage in inquiry learning is the investigation stage of the curiosity process embodied in the real form of answering questions or hypotheses proposed in the previous stage (Scanlon, Anastopoulou, \& Mulholland, 2011). Critical thinking skills in the well-trained analysis aspect through information exploration activities will encourage students to develop an 
honest, meticulous, polite, well-communicated, and respectful attitude, to have the ability to gather information in a variety of ways, and to develop good learning habits. Students who have these skills will also gain experience from the activities undertaken ( (Maybee, Bruce, Lupton, \& Rebmann., 2016; Musfiqon \& Nurdiansyah, 2015). The syntax of information exploration is based on Bruner's learning theory of discovery where students can undertake a number of learning activities such as exploring literature, laboratory activities, and outside activities that can help them use their initial knowledge to generate new ideas, explore questions, and produce preliminary designs and inventions (Bruner, 1977; Dahar, 2011).

The syntax of discussion in the Stim-HOTs model is effective in training the aspects of critical-thinking skills on the aspects of analysis and evaluation. This syntax activity was carried out by discussing the information obtained and analyzed in the previous stage; then the students evaluated what had been analyzed. The teacher, at the discussion stage, asked the students to discuss the results of the experiment or the gathering of information that had been done and analyzed them. They responded by discussing what had been obtained and verifying with the existing theories to summarize their findings. The information obtained by the students were then processed with various sources of information in depth and more widely to obtain information that supports each other, or is different even contradictory (Musfiqon \& Nurdiansyah, 2015; Pedaste et al., 2015; Scanlon, et al., 2011). The effectiveness of discussion syntax in the Stim-HOTs model is based on social constructivism theory by Vygotsky about the training of the aspects of analysis and evaluation because at this stage, students analyzed the findings in groups and evaluated the results of the information extracting (Schunk, 2012). Therefore, this syntax of discussion prioritizes the role of the set-up social systems between students and students.

The explanation syntax in the Stim-HOTs model is effective in training the aspects of critical thinking skills on aspects of analysis and conclusion. These aspects were trained through the students' activities by conveying the results of the discussion to provide a conclusion and explanation of the things that are important about the concepts studied. In the explanation stage, the students explained the findings of information that aims to answer the questions/problems/cases presented in the class. If there is one group that presents the findings, then the other group will be a buffer (Afandi \& Sajidan, 2017; Afandi et al., 2017). Various activities of explanation syntax can be done either by classical presentation or by the window-shopping method. This stage is also related to communication activities that can make students able to convey the findings and conclusions. The activities in this stage also made the students give comments and feedbacks to their friends (Lim, 2004; Runnel \& Pedaste, 2013; Scanlon, et al., 2011). The explanatory syntax based on Dewey's reflective thinking theory trains the aspects of conclusions and explanations because, at this stage, students are required to conclude the results of the discussion or findings and then explain the findings of information aimed at answering the questions or problems presented. Therefore, the explanation syntax becomes an important stage in training critical-thinking skills especially the aspects of conclusions and explanations. 
The self-reflection syntax in the Stim-HOTs model is able to train students' selfregulation. In this stage, there is the cultivation of students' activities related to the prevailing moral values, the internalization of scientific attitudes, and the appreciation of the greatness of God Almighty (Afandi \& Sajidan, 2017; Afandi et al., 2017). The syntax of self-reflection developed in the Stm-HOTs model is an important stage that can lead one to have good self-regulation. Students who have good self-regulation will be able to achieve good learning outcomes and have high motivation in learning (Alrawahi \& Al-balushi, 2015; Daniela, 2015). The self-reflection syntax based on Dewey's reflective thinking theory and Marzano's idea of habits of mind trains the self-regulation aspect because it is the process that aims to encourage students to know how effective learning processes are for them. Marzano \& Pickering (2001) proposed a theory of learning dimensions translated into dimensions of thinking that became the framework used by K-12 teachers (The Kindergarten to 12-Year Basic Education) to improve the quality of learning and teaching.

The effectiveness of the Stim-HOTs model on cell-metabolism topic on the activities that improve the aspects of critical -thinking skills is also supported by the observations of the teacher and the students' activities during the learning process. The observations on the implementation of the Stim-HOTs model syntaxes ran well, suggesting that the Stim-HOTs model has proven effective in empowering critical-thinking skills in cell metabolism topic. However, the empowerment of critical-thinking skills in students also involves many other factors such as the characters of psychology, intelligence, and the learning environment (Budsankom, Sawangboon, \& Damrongpanit 2015). Therefore, in empowering these skills in students, teachers need to develop appropriate pedagogy in developing it and take appropriate steps for critical-thinking skills to be well empowered (Marin \& Halpern, 2011). Teachers are also required to have the ability to manage the class well and facilitate students to engage in active learning so that the students are accustomed to using information well and not just receive information (Aun \& Kaewurai, 2017).

Critical-thinking skills are high-level thinking skills capable of forming students who are able to think neutrally, objectively, reasonably or logically. Therefore, good criticalthinking skills will be of great benefits to students either in the short term at school or later in the long term in the world of work in their future lives (Cottrell \& Cottrell, 2005). Critical thinking skills will also help students to face the challenges of the $21^{\text {st }}$ century especially in the era of disruptive innovation where many innovations emerge (Wan, 2015).

\section{CONCLUSION}

Based on the results of this study, it can be concluded that Stimulating Higher-OrderThinking Skills (Stim-HOTs) model applied to cell metabolism topic can improve students' critical-thinking skills. The effectiveness of the Stim-HOTs model can be seen from the ANCOVA test shows that there is an effect of using Stim-HOTs learning models for improving students' critical thinking skills with results of the covariance analysis obtained $\mathrm{F}$ count of 13.445 and significance of 0.001 , while the result of effect size test is in the large criterion. The result from the average score significance of the 
critical-thinking skills gain score calculation in the experimental class is higher by 0.66 compared to the existing class of 0.51 in the medium criterion. This gain score increase occurs in every aspect of students' critical-thinking skills in the medium criterion. Therefore, critical-thinking skills in every aspect of interpretation, analysis, evaluation, conclusion, explanation, and self-regulation can be effectively enhanced through the activities of the Stim-HOTs model.

This research is limited to cell metabolism material in the $12^{\text {th }}$ grade of senior high school. This research will be more interesting if it can be applied to other subject matter in the study of biology or natural science conducted at different levels of class. This research is also still limited to the effectiveness of the Stim-HOTs model in empowering students' critical thinking skills so that in the future it needs to be examined how this model can be integrated with other activities in learning so that it can improve 4Cs skills namely communication, collaboration, critical thinking and problem solving, creativity and innovation.

\section{ACKNOWLEDGMENTS}

The researcher would like to thank LPPM (Development and Community Service Institution) of Sebelas Maret University for funding this research with PNBP Fund with contract No.543/UN 27.21/PP/2018.

\section{REFERENCES}

Adeyemi, S.B. (2012). Developing Critical Thinking Skill in Students: A Mandate for Higher Education in Nigeria. Europian Journal of Education Research, 1(2), 155-161.

Afandi \& Sajidan. (2017). Stimulasi keterampilan berpikir tingkat tinggi: konsep dan implementasinya dalam pembelajaran abad 21 [Stimulating higher order thinking skill: the concept and its implementation in $21^{\text {st }}$ century learning]. Surakarta: UNS Press.

Afandi, Sajidan, Akhyar, M., \& Suryani, N. (2017). Buku panduan model stimulasi keterampilan berpikir tingkat tinggi [Guidance book of stimulating higher order thinking skill model]. Surakarta: UNS.

Al-rawahi, N. M., \& Al-balushi, S. M. (2015). The Effect of Reflective Science Journal Writing on Students' Self-Regulated Learning Strategies. International Journal of Environmental \& Science Education, 10(3), 367-379.

Anderson, L.W. \& Krathwol, D.R. (2015). Kerangka landasan untuk pembelajaran, pengajaran, dan asesemen (revisi taksonomi Bloom) [framework for learning, teaching, and assessment (revision of Bloom's taxonomy]). Yogyakarta: Pustaka Pelajar.

Arsal, Z. (2017). The Impact of Inquiry-Based Learning on the Critical Thinking Dispositions of Pre-service Science Teachers. International Journal of Science Education, (May), 1-11.

Aun, S., \& Kaewurai, W. (2017). Instructional Model Development to Enhance Critical Thinking and Critical Thinking Teaching Ability of Trainee Students at Regional 
Teaching Training Center in Takeo Province, Cambodia. Kasetsart Journal of Social Sciences, 38, 88-95.

Bruner, J.S. (1977). The proccess of education. USA: Harvard University Press.

Budsankom, P., Sawangboon, T., \& Damrongpanit, S. (2015). Factors Affecting Higher Order Thinking Skills of Students: A Meta-Analytic Structural Equation Modeling Study. Educational Research and Review, 10(19), 2639-2652.

Chu, S.K.W., Reynold, R.B., Tavares, N.J., Notari, M. (2017). $21^{\text {st }}$ century skills development through inquiry-based learning from theory to practice. Singapore: Springer.

Cohen, J. (1988). Statistical power analysis for the behavioral sciences $\left(2^{\text {nd }}\right.$ edition). Hillsdale, NJ: Erlbaum.

Cottrell, S., \& Cottrell, O. S. (2005). Developing effective analysis and argument. library. New York: Palgrave MacMillan.

Creswell, J.W. (2012). Educational research. Boston: Pearson.

Dahar, R.W. (2011). Teori-teori belajar dan pembelajaran [learning theory]. Jakarta: Erlangga.

Daniela, P. (2015). The Relationship between Self-Regulation, Motivation and Performance at Secondary School Students. Procedia - Social and Behavioral Sciences, 191, 2549-2553.

Eggen, P. \& Kauchak, D. (2012). Strategi dan model pembelajaran mengajarkan konten dan keterampilan berpikir. Translated by Satrio Wihono. Jakarta: PT Indeks Permata Putri Media.

Ennis, R. H. (2011). The Nature of Critical Thinking: An Outline of Critical Thinking Dispositions and Abilities. University of Illinois. Retrieved from http://faculty.education.illinois.edu/rhennis/documents/TheNatureofCriticalThinking_51 711_000.pdf

Facione, P.A.(2011). Think critically. New York: Pearson Education.

Facione, P.A. (2015). Critical thinking:what it is and why it counts, (Online). Retrieved from http:// www.insightassessment.com/pdf).

Fuad, N. M., Zubaidah, S., Mahanal, S., \& Suarsini, E. (2017). Improving Junior High Schools' Critical Thinking Skills based on Test Three Different Models of Learning. International Journal of Instruction, 10(1), 101-116.

Glass, G.V. (1976). Primary, secondary, and meta-analysis of research. Educational Researcher, 5(10). 3-8.

Hairida. (2016). The Effectiveness using Inquiry-Based Natural Science Module with Authentic Assessment to Improve the Critical Thinking and Inquiry Skills of Junior High School Students. Jurnal Pendidikan IPA Indonesia, 5 (2), 209-215. 
Hake, R.R. (1999). Analyzing change/ gain score. CA,USA: Indiana University.

Hedges, L.V. (1981). Distribution Theory for Glass Estimator of Effect Size and Related Estimators. Journal of Educational Statistics, 6 (2), 107-128.

Husamah, Fatmawati, D., \& Setyawan, D. (2018). OIDDE Learning Model: Improving Higher Order Thinking Skills of Biology Teacher Candidates. International Journal of Instruction, 11(2), 249-264.

Husamah \& Setyaningrum, Y. (2013). Desain pembelajaran berbasis pencapaian kompetensi: panduan merancang pembelajaran untuk mendukung implementasi kurikulum 2013 [Competency-based learning design: a guide to designing learning to support the implementation of the 2013 curriculum ]. Jakarta: Prestasi Pustakaraya.

Jeffery, E., Nomme, K., Deane, T., Pollock, C., \& Birol, G. (2016). Investigating the Role of an Inquiry-Based Biology Lab Course on Student Attitudes and Views Toward Science. CBE-Life Sciences Education, (Winter), 1-12.

Lim, B. (2004). Challenges and Issues in Designing Inquiry on the Web. British Journal of Educational Technology, 35(5), 627-643.

Lin, C., Li, B., \& Wu, Y. J. (2018). Existing Knowledge Assets and Disruptive Innovation: The Role of Knowledge Embeddedness and Specificity. Sustainability, $10(342), 1-15$.

Lotter, C. R., Thompson, S., Dickenson, T. S., \& Smiley, W. F. (2016). The Impact of a Practice-Teaching Professional Development Model on Teachers' Inquiry Instruction and Inquiry Efficacy Beliefs. International Journal of Science and Mathematic Education, November, 1-19.

Mahanal, S., Zubaidah, S., Bahri, A., \& Dinnuriya, M. (2016). Improving Students' Critical Thinking Skills through Remap NHT in Biology Classroom. Asia-Pacific Forum on Science Learning and Teaching, 17(1), 1-19.

Mcnew-birren, J., \& Kieboom, L. A. Van Den. (2017). Exploring the Development of Core Teaching Practices in the Context of Inquiry-Based Science Instruction: An Interpretive Case Study. Teaching and Teacher Education, 66, 74-87.

Marin, L.M. \& Halpern, D.F. (2011). Pedagogy for Development Critical Thinking in Adolences: Explicit Instruction Producer Greatest. Journal of Thinking Skill and Creativity, 6, 1-13.

Marzano, R.J. \& Pickering, D.J. (2006). Dimensions of learning (2nd edition). Hawker Browlaw Education.

Maybee, C., Bruce, C. S., Lupton, M., \& Rebmann, K. (2016). Designing Rich Information Experiences to Shape Learning Outcomes. Studies in Higher Education, 5079(April), 1-16.

Musfiqon \& Nurdiansyah. (2015). Pendekatan saintifik [scientific approach]. Sidoarjo: Nizamia Learning Center. 
Muspikawijaya, Iswari, R. S., \& Marianti, A. (2017). Analisis Kesulitan Peserta Didik SMA/MA Kabupaten Luwu Timur Dalam Memahami Konsep Pada Materi Matabolisme Sel [Analysis of the difficulties of high school students in East Luwu Regency in understanding the concept of cell metabolism material]. Journal of Innovative Science Education, 6(2), 252-263

OECD. (2010). PISA 2009 results: learning trends: changes in student performance since 2000 (Volume V).

OECD. (2014). PISA 2012 results: what students know and can do - student performance in mathematics, reading and science (volume $i$, revised edition, february 2014), PISA:OECD Publishing.

OECD.(2016). PISA 2015 result in focus. PISA: OECD Publishing.

Partnership for $21^{\text {st }}$ Century Skills (P21). (2015). Framework for 21 st century learning. Retrieved from P21 Partnership for 21st Century Skills. Retrieved from http://www.p21.org/our-work/p21-framework.

Pedaste, M., Mäeots, M., Siiman, L. A., Jong, T. De, Zacharia, Z. C., \& Tsourlidaki, E. (2015). Phases of Inquiry-Based Learning: Definitions and the Inquiry Cycle. Educational Research Review, 14, 47-61.

Piaget, J. (2003). The psychology of intelligence. London: Taylor and Francis e-Library.

Pithers, R.T \& Soden, R. (2010). Critical Thinking in Education: A Review. Educational Research, 45 (3).

Runnel, M. I., \& Pedaste, M. (2013). Model for guiding reflection in the context of inquiry-based science education. Journal of Baltic Science Education, 12(1), 107-118.

Saputri, A.C., Sajidan, \& Rinanto, Y. (2018). Critical thinking profile of senior high school students in Biology learning. Journal of Physics: IOP Conference Series. 1006 012002 .

Scanlon, E., Anastopoulou, S., \& Mulholland, P. (2011). How Technology Resources can be Used to Represent Personal Inquiry and Support Students' Understanding of it Across Contexts. Journal of Computer Assisted Learning, 27, 516-529.

Schunk, D.H. (2012). Teori-teori pembelajaran perspektif pendidikan [Learning theory in education prespective]. Translated by Eva Hamidah \& Rahmat Fajar. Yogyakarta: Pustaka Pelajar.

Setiawati, H., \& Corebima, A. D. (2017). Empowering Critical Thinking Skills of the Students Having Different Academic Ability in Biology Learning of Senior High School Through PQ4R - TPS Strategy. The International Journal of Social Science and Humanities Invention, 4(5), 3521-3526.

Sing, C., \& Kong, C. S. (2017). Professional Learning for $21^{\text {st }}$ Century Education. Journal of Computers in Education, 4(1), 1-4. 
Sripongwiwat, S., Bunterm, T., Srisawat, N., \& Tang, K. N. (2016). The Constructionism and Neurocognitive-based Teaching Model for Promoting Science Learning Outcomes and Creative Thinking. Asia-Pacific Forum on Science Learning and Teaching, 17(2), 1-33.

Sullivan, G.M. \& Feinn, R. (2012). Using Effect Size-or Why the p Value is not Enough. Journal of Graduate Medical Education, 279-282.

Suprapto, N. (2016). What should educational reform in Indonesia look like? Learning from the PISA Science Scores of East-Asian Countries and Singapore. Asia-Pacific Forum on Science Learning and Teaching, 17(1), 1-21.

Synder, L.G., \& Synder, M.G. (2008). Teaching Critical Thinking and Problem Solving. Delta Pi Epsilon Journal, 50 (2).

Swart, R. (2017). Purposeful Use of Technology to Support Critical Thinking. JOJ Nurse Health Care, 4(1), 1-9.

Taleb \& Chadwick. (2016). Enhancing Students Critical Thinking Skill and Analitycal Thinking Skill at the Higher Education Level in Developing Countries: Case Study in Dubai. Journal of Education and Instructional Studies in the World, 6 (1).

Tofade, T., Jamie, E., \& Haines, S. T. (2013). Best Practice Strategies for Effective Use of Questions as a Teaching Tool. American Journal of Pharmaceutical Education, 77(7), 155.

Uum, M. S. J. Van, Verhoeff, R. P., \& Peeters, M. (2017). Inquiry-based Science Education: Scaffolding Pupils' Self-directed Learning in Open Inquiry. International Journal of Science Education, O(0), 1-21.

Uzoamaka, E. C., Okafor, C. O., \& Akusoba, E. U. (2014). The Impact of Teacher Errors on Senior Students' Understanding of Concept Respiration in Swka. International Journal of Scientific and Research Publications, 4(11), 2-5.

Vanderlelie, J. J. (2013). Improving the Student Experience of Learning and Teaching in Second year Biochemistry: Assessment to Foster a Creative Application of Biochemical Concepts. International Journal of Innovation in Science and Mathematics Education, 21(4), 46-57.

Wan, F., Williamson, P. J., \& Yin, E. (2015). Technovation Antecedents and Implications of Disruptive Innovation: Evidence from China. Technovation, 40, 94-96.

Wenning, C. J. (2011). The Levels of Inquiry Model of Science Teaching. Journal of Physics Teacher Education (Online), 6(2), 9-16.

Yang, Y. C., Newby, T. J., \& Bill, R. L. (2005). Using Socratic Questioning to Promote Critical Thinking Skills through Asynchronous Discussion forums in Distance Learning Environments. American Journal of Distance Education, 19(3), 163-181. 